\title{
Models and Mechanisms of Network Interaction Between Universities and the Real Sector of the Economy in the Field of Innovation
}

\author{
O.N. Kukharev ${ }^{1}$, A.V. Nosov ${ }^{1}$, A.A. Tuskov ${ }^{2,3, *}$, E.S. Grosheva ${ }^{2,3}$ \\ ${ }^{1}$ Penza State Agrarian University, Penza, 440014, Russia \\ ${ }^{2}$ Penza State University, Penza, 440026, Russia \\ ${ }^{3}$ Moscow State University of Technologies and Management named after K.G. Razumovskiy, Moscow, Russia \\ *Corresponding author. E-mail: tuskov@mail.ru
}

\begin{abstract}
The scenario for the long-term development of the domestic economy as defined in Russia's Innovative Development Strategy implies the growth of its competitiveness in both traditional and new high-tech sectors, a breakthrough in improving the quality of human capital and the dynamics of labor productivity, in the accelerated development of high-tech industries and the transformation of innovative factors into the main source of economic growth. In this case a priority role in the formation and implementation of innovation-based strategy for renewal and development of the economy should belong to the high school, as an important source of intellectual potential.
\end{abstract}

Keywords: innovation, knowledge economy, real sector of the economy, networking, brokerage

\section{INTRODUCTION}

Best domestic and foreign practices demonstrate that for the comprehensive realization of the potential of universities, coordinated efforts of both educational institutions combining their educational, scientific, technological and human resources for effective training of personnel and scientific and innovative activities, as well as the main consumers of university results, the real sector of the economy, are necessary.

The problem of interaction between universities and enterprises in order to intensify innovative processes is considered in many modern management concepts.

In particular, in studies on the knowledge economy [1], there is a shift in emphasis in the management of organizations from managing material flows to managing information, competencies, institutions, and knowledge. Their productive use in various sectors of the economy is central to this concept.

The practical implementation of network interaction between universities and the real sector of the economy in the field of innovation is today problematic, and the effectiveness and efficiency of such cooperation is ineffective and does not allow for the comprehensive realization of the innovative potential of each participant.

\section{ACTUAL TASKS OF HIGH SCHOOL NETWORKING AND THE REAL SECTOR OF THE ECONOMY TO INCREASE THE EFFECTIVENESS OF COLLABORATIVE INNOVATION}

We can distinguish the following urgent problems of interaction between higher education and the real sector of the economy for modern Russia:

1) the different attitude of universities and enterprises to the degree of openness of the results of research and development;

2) the desire of enterprises to lure highly qualified labor resources (teaching and research personnel of universities); 3 ) the desire of each subject to achieve a dominant position in the implementation of joint projects;

4) the asymmetry of the resource contribution to joint projects by various participants and the distribution of risks; 5) poor use of modern forms and technologies of interaction in joint project activities of universities and entities of the real sector of the economy when implementing partnership projects, including due to the underdeveloped network infrastructure for organizing such interaction. We can distinguish the following urgent problems of interaction between higher education and the real sector of the economy for modern Russia:

1) the different attitude of universities and enterprises to the degree of openness of the results of research and development;

2) the desire of enterprises to lure highly qualified labor resources (teaching and research personnel of universities); 3) the desire of each subject to achieve a dominant position in the implementation of joint projects;

4) the asymmetry of the resource contribution to joint projects by various participants and the distribution of risks; 5) poor use of modern forms and technologies of interaction in joint project activities of universities and entities of the real sector of the economy when implementing partnership projects, including due to the underdeveloped network infrastructure for organizing such interaction. 
It is worth noting that world trends in the development of universities, their role and place in ensuring the competitiveness of the national economy justify the emphasis on higher education and its positioning as the leading subject of building a national innovation system and its nature of interaction with the main elements of the economic system and the presence of unique distinctive features ( developed network, concentration of intellectual potential, fulfillment of the strategically important function of forming an "innovative person") allows applying for the role of a leading subject of innovation.

In this regard, we can formulate the following list of urgent tasks in the field of network interaction between higher education and the real sector of the economy to increase the effectiveness of joint innovation:

1) training for various sectors of the national economy, primarily for its priority areas:

a) the development of technology and infrastructure for the implementation of educational programs based on elearning to improve the quality and accessibility of training; b) the development of network learning technologies that provide students with the opportunity to master the program using the resources of several organizations engaged in educational activities;

c) development of a system of continuous training, support and support of the current activities of specialists in the framework of the implementation of continuing education programs;

d) the introduction of effective mechanisms for the participation of enterprises in the formation of an order for the training of specialists (including the formation of professional educational standards), ensuring the demand for university graduates and minimizing the period of their adaptation at workplaces;

2) universities should be the main basis for basic scientific research, creating conditions for the technological development of the economy:

a) the spread of network forms of interaction (including professional networks) to increase the effectiveness of communications between subjects of research activities, the joint work of various scientific groups, including geographically distant from each other, on common projects;

b) the development of network channels for disseminating research results on university projects;

3) commercialization of the results of university research and development, other results of innovation through specialized objects of innovation infrastructure and interaction mechanisms:

a) the formation of modern network structures (virtual business incubators, network knowledge brokers, professional social networks, etc.) that allow for the continuous networking of universities with participants in innovative activities;

b) the development of specialized software environments for network interaction between participants in innovation. The solution of these problems is able to harness the potential of modern universities to solve pressing problems of innovative development and increase the competitiveness of the domestic economy.

\section{NETWORK INTERACTION OF UNIVERSITIES AND THE REAL SECTOR OF THE ECONOMY}

With the development of national innovation systems in developed countries, new approaches to explaining the processes of emergence and diffusion of innovations, corresponding to the modern stage of development, appear. Studies on the theory of innovation analyze the properties and new patterns that, in various forms, are reflected in the interaction of the state, science and business and take the form of "The Triple Helix Concept".

The Triple Helix concept was developed by Henry Itskowitz (Stanford University) and Loyet Leidesdorf (University of Amsterdam). It describes innovative development through the dynamics of relations between the university, industry (business) and government (government) at the national and regional levels (Fig. 1). The triple helix model assumes that it is universities that become centers that generate technologies and new forms of entrepreneurship, leaving behind scientific research [2].
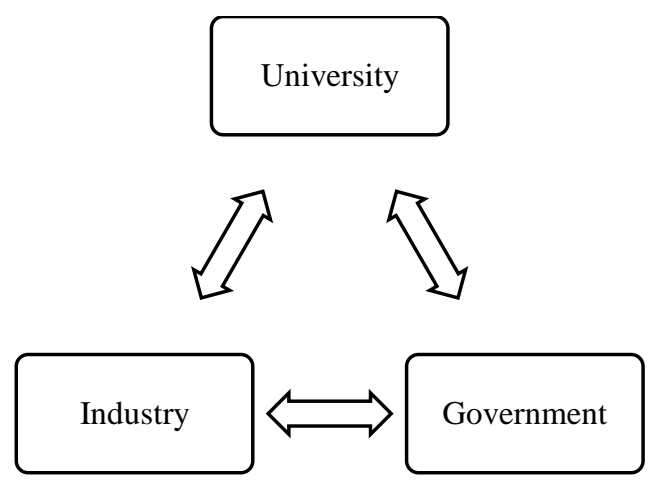

Figure 1 Triple Helix Model

As the authors Dezhina I., Kiselev, Russia still exist and develop only "double", not "triple helix" of relations between subjects of innovative activity. There are four types of such visible pair bonds [3]:

1. State - the public sector science.

2. State - commodity industries.

3. The state - the rest of the business.

4. Science - business [4].

The state's role is to promote and finance the development of research centers that bring together more and more universities, institutes, companies around themselves, creating a scientific and educational network. To ensure the interaction between science and business, a whole set of diverse intermediaries is required. Intermediaries form the environment for the implementation of innovative activities (innovation infrastructure). These organizations include: 1) business incubators and technology incubators designed to support small, predominantly innovative entrepreneurship by providing leased premises to newly created firms, as well as providing them with consultations on the organizational and economic aspects of their activities; 
2) technology parks that are creating a territorial innovation environment in order to create the material and technical base for the establishment and preparation for independent activity of small innovative enterprises, as well as for the purpose of the industrial development of scientific knowledge and high technology;

3) public associations of innovative enterprises created to protect the interests of entrepreneurs. They assist in the registration of enterprises, patenting of intellectual property, finding partners and sources of financing, etc .;

4) service commercial (in whole or in part) organizations providing information services to firms, providing them with consulting, audit, advertising and other types of services [5].

The activities of the university within the framework of this infrastructure are as follows:

- implementation of socially significant projects;

- collaboration of researchers and teachers in the development of an innovative economy;

- the provision of telecommunication and organizational services for the provision of training courses developed by the consortium of traditional educational institutions for distance learning on the basis of a variety of educational technologies under the terms of agreements on joint educational activities.

\section{BROKERAGE-BASED KNOWLEDGE TRANSFER SYSTEM MODEL}

As a compensation mechanism for market imperfections and lack of competence from the producer or consumer of knowledge appropriate to use knowledge brokerage. Knowledge brokerage is an activity for the search, processing, processing and transfer of knowledge, taking into account the requirements of the consumer and in a form suitable for assimilation, carried out by a knowledge broker on the basis of its creative resources and social capital.

The broker's fundamental asset is his "know-how" knowledge as a combination of his social connections and the experience of the communications made. In the course of interaction with various participants of their social network, the social capital of the broker is created, which consists in gaining experience of interpersonal interaction with various subjects. For the most part, this knowledge is implicit and cannot be fully codified. In addition, "knowhow" knowledge can be used to create metacognition, that is, "knowledge of knowledge" [6].

Metaknowledge allows the broker to some extent codify the "asset map" of his social network. The unique competence or brokers know-how of lies in their ability to commercialize knowledge.

As we have already noted, the motivation and, accordingly, attitude to knowledge among representatives of science and business are fundamentally different. If scientific organizations strive to create new knowledge, then for commercial organizations, the priority is the use of knowledge for profit. Knowledge brokers are focused on the commercialization and practical application of any scientific or technological knowledge.

From the position of ensuring the effective functioning of the national innovation system, knowledge brokers are unique because they act as "altruists of innovation" - not burdened with corporate tasks of preserving intellectual rent and an idealistic idea of "science for science", brokers seek to disseminate any useful knowledge in the real sector of the economy.

Another important function of knowledge brokers is the organization and coordination of interaction spaces. Based on ICT communication tools, a knowledge-sharing space independent of the physical location of subjects can be created in which new distributed knowledge systems network business incubators and online electronic universities - can be formed.

Thus, the model of a knowledge transfer system based on brokerage within the framework of the functioning of the information environment of the network interaction between universities and the real sector of the economy will have the following form (Fig. 2).

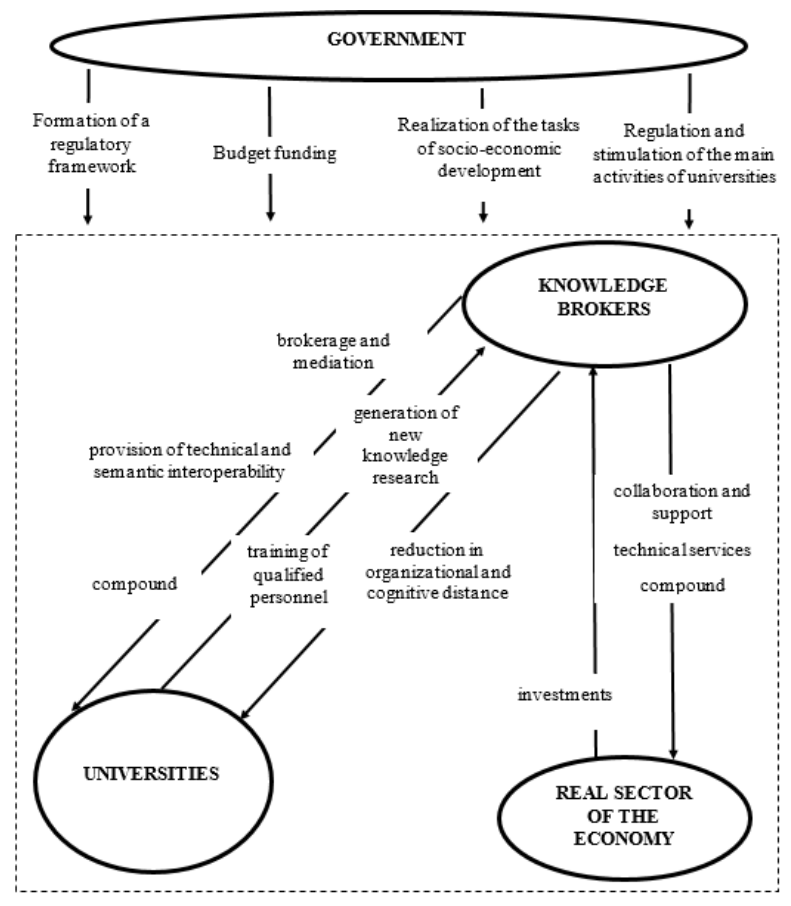

Figure 2 Brokerage-based knowledge transfer system model

Thus, knowledge brokerage is not only a popular service for private companies aimed at improving the efficiency of their own innovative activities, but also a catalyst for innovative development across the national economy.

\section{CONCLUSION}

As a result of scientific analysis, we determined that as a market imperfection compensation mechanism of 
knowledge, low absorptive capacity of the recipient's knowledge and the distance between producers and consumers of knowledge it is advisable to use the brokerage knowledge, which refers to the process of finding, treatment, processing and transmission of knowledge and information, taking into account customer requirements and in suitable form for assimilation, carried out by the broker of knowledge on the basis of its creative resources and social capital.

In our opinion, the development of specialized institutional structures that perform the functions and tasks of knowledge brokerage can provide a significant intensification of innovative activity in various segments of the national economy [7].

Implementation of the proposed models and methods for managing knowledge sharing processes, as well as the developed recommendations, allow us to identify key elements of a knowledge management strategy and increase the effectiveness of interaction between subjects of innovative activity.

\section{REFERENCES}

[1] Gaponenko A. L., Orlova T. M. Management of knowledge. How to turn knowledge into the capital [Upravlenie znaniyami. Kak prevratit' znaniya v capital]. M.: Eksmo, 2008. (rus).

[2] Itskowitz G. Triple Helix. Universities - enterprises - state. Innovation in action. [Troynaya spiral'.

Universitety - predpriyatiya - gosudarstvo. Innovatsii v deystvii.] Tomsk: TUSUR Publishing House, 2010. 238 p. (rus).

[3] Dezhina I., Kiseleva V. “Triple Helix” in Russia’s Innovation System. Voprosy Ekonomiki. 2007;(12) 123-135. (In Russ.) DOI:

https://doi.org/10.32609/0042-8736-2007-12-123-135

[4] Katukoff D., Malyguin V., Smorodinskaya N. Institutional Environment ina Globalized Economy: the Development of Network Interactions, ed. Smorodinskaya N.Moscow, Institute of Economy, Russian Academy of Sciences,. 2012. - 45 p.

[5] Knyazev E.A., Drantusova N.V. Networks in Vocational Education. [Seti v professionalnom obrazovanii]. Universitetskoe upravlenie, 2010, no. 5, pp. 24-31.

[6] Ponomarev N.L., Smirnov B.M. Educational Innovation: Public Policy and Management. [Obrazovatel'nyye innovatsii: Gosudarstvennaya politika i upravleniye.] M. Academy, 2008, 208 p.

[7] Krevsky I. G., Artamonova Yu. S., Divnenko Z. A., Glotova T. V., Matyukin S. V., Tuskov A. A., Shlenov Yu. V., Shlenova M. Yu., Yudina E.S., Network technologies in economics and education, Collective monograph. [Setevyye tekhnologii v ekonomike i obrazovanii], Penza, 2016, 227 p. (rus). 